\title{
Seed fortification studies in barnyard millet (Echinochloa frumentacea) cv. CO1
}

\author{
K. Sujatha, K. Selvarani, V.Vijayalakshmi, C.Vanniarajan", and \\ K. Sivasubramaniam \\ Department of Seed Science and Technology, * Department of Plant Breeding and Genetics Agricultural \\ College and Research Institute, Madurai - 625104
}

\begin{abstract}
Studies on barnyard millet (kuduraivali) seed fortification with different macro and micronutrients such as $\mathrm{KH}_{2} \mathrm{PO}_{4}(1 \%), \mathrm{ZnSO}_{4}(0.1 \%), \mathrm{FeSO}_{4}(0.2 \%), \mathrm{Na}_{2} \mathrm{SO}_{4}(0.1 \%)$ and $\mathrm{KCl}(1 \%)$; growth regulators viz., $\mathrm{GA}_{3}(100 \mathrm{ppm}), \mathrm{IAA}(100 \mathrm{ppm})$ and Thiourea (1\%) along with water soaked and untreated seeds (control) revealed the enhanced performance of 100 ppm IAA over other chemicals by recording 18 per cent higher germination than control. The hike in germination was also supported by the enhancement in the evaluated vigour parameters viz., speed of germination, seedling length, dry matter production and vigour index followed by $\mathrm{KH}_{2} \mathrm{PO}_{4}(1 \%)$ treated seeds. The untreated seeds recorded the least values for all parameters,

Key words: Seed fortification, Macro and Micronutrients, Growth Regulators, Kuduraivali seeds
\end{abstract}

\section{Introduction}

Barnyard millet is a fair source of highly digestible protein and an excellent source of dietary fiber with reasonable quantity of soluble and insoluble fractions. The carbohydrate content is low and slowly digestible, which makes the barnyard millet a nature's gift for the modern humans engaged in sedentary activities. The grains of barnyard millet are low in phytic acid and rich in iron and calcium (Sampath et al., 1990). It is cultivated for its small grains which are borne on short, slender, grassy plants for grown under arid, semi arid or mountain zones as rainfed crop it is subjected climatic vagaries which is the main cause for loss in productivity. Consistency and stability in production is the need of the hour, hence efforts in this direction alone can help in harnessing the tremendous potential of the crop. Macro and micronutrients and plant growth regulators are vital for plant growth and development. Though micronutrients are required in relatively smaller quantities for plant growth, they are essential elements in physiological process like respiration, photosynthesis (Mengel et al., 2001). Seed germination and seedling growth are known to be regulated by exogenous hormones (Mehrotra et al., 1968, Khan, 1977, Singh and Murthy, 1987, Verma and Tandon, 1988, Virendra Singh, 1990). Seed fortification is a pre sowing seed management technique; where, essential and needy bioactive substances can be added to improving the initial stamina of the seed for higher germinability, seedling vigour and field stand. Seed fortification with plant growth regulators and inorganic nutrients have already been reported (Renugadevi et al., 2008 in cluster bean and Ponnuswamy et al., 2011 in solanaceous vegetables). Reports on barnyard millet on seed fortification are scanty. Hence, present investigation was carried out to identify the effect of seed fortification on seed quality parameters in barnyard millet.

\section{Materials And Methods}

Genetically pure seeds of barnyard millet cv. CO1 obtained from Department of Plant Breeding and Genetics, Agricultural College and Research Institute, Madurai for the study. Seeds were subjected to fortification treatments viz., soaking in water, macro and micronutrients $\left(1 \% \mathrm{KH}_{2} \mathrm{PO}_{4}, 0.1 \% \mathrm{ZnSO}_{4}, 0.2 \%\right.$ $\mathrm{FeSO}_{4}, 0.1 \% \mathrm{Na}_{2} \mathrm{SO}_{4}$ and $1 \% \mathrm{KCl}$ ) and growth regulators (100 ppm GA $3,100 \mathrm{ppm}$ IAA and $1 \%$ Thiourea ) for $16 \mathrm{~h}$ in 1: 0.6 ratio of seed to water and shade dried, un treated dry seeds served as control. The experiment was conducted in a factorial completely randomized design (FCRD). Observations on germination (\%), speed of germination, seedling length $(\mathrm{cm})$, dry matter production (g. seedling ${ }^{-10}$ ), vigour index were recorded. The germination test was carried out as per the procedure prescribed by ISTA with four replicates of 100 seeds each in roll towel medium. Observations for seedling traits were recorded on ten randomly selected seedlings by drying under shade for $24 \mathrm{~h}$ and then in hot air oven maintained at $85 \pm 1^{\circ} \mathrm{C}$ for $48 \mathrm{~h}$. It was cooled in a desiccator for $30 \mathrm{~min}$ and weighed. The values were expressed as mg.seedlings ${ }^{-10}$. Vigour index was calculated by using the formula of Abdul Baki and Anderson (1973), Vigour index $=$ Germination \% x Seedling length (cm). The data recorded were analyzed statistically as per Panse and Sukhatme (1985). 


\section{Results And Discussion}

Among the micro, macro nutrients and growth regulators treatments, barnyard millet seeds fortified for $16 \mathrm{~h}$ with $100 \mathrm{ppm}$ IAA recorded higher germination, speed of germination, seedling length, dry matter production and vigour index $(96 \%, 17.25,20.60 \mathrm{~cm}, 0.029 \mathrm{~g}$ and 2016 respectively) followed by seeds fortified with $1 \% \mathrm{KH}_{2} \mathrm{PO}_{4}$. The treatment IAA $100 \mathrm{ppm}$ recorded $18 \%$ higher germination, 5.58 days earlier in speed of germination, $11 \%$ in seed length, $3.80 \%$ in dry matter and $21 \%$ in vigour index increase over than untreated control (fig 1-5). Sodium sulphate was harmful while $\mathrm{GA}_{3}$ did not improve germination. Rapid, uniform and early germination is a prerequisite for good establishment and survival of the seedlings in the field of any crop species. In the present investigation, higher germination and seedling vigour were observed due to seed fortification with $100 \mathrm{ppm}$ IAA followed by $1 \% \mathrm{KH}_{2} \mathrm{PO}_{4}$ and $0.2 \% \mathrm{FeSO}_{4}$, which was attributed to micronutrients and growth regulators that often act as co - factors in enzyme systems and participate in redox reactions, in addition to having several other vital seed functions. Most importantly, they are involved in the key physiological processes (Marschner, 1995 and Mengel et al. 2001). The results were in agreement with the findings of Renugadevi and Selvaraj (1994) in bitter gourd seeds; Geetha et al. (2011) in soybean; Raja et al. (2011) in rice, who reported the positive role of nutrients in improving germination. According to Woodstock (1969) germination rate and percentage could be increased in tomato seeds by soaking in solution of $2 \%$ $\mathrm{KH}_{2} \mathrm{PO}_{4}$ and then drying back.

Based on the results it can be concluded that germination and seedling quality of barnyard millet was enhanced by seed fortification with IAA $(100 \mathrm{ppm})$ or $\mathrm{KH}_{2} \mathrm{PO}_{4}(1 \%)$ and can serve as a pre sowing seed treatment.

\section{References}

[1]. Abdul-Baki A A and Anderson J D. 1973. Vigour determination in soybean seed by multiple criteria. Crop Sci., 13: 630 - 633.

[2]. Geetha B, Sucheta S and Gill B S. 2011. Pre sowing seed treatments and qualityinvigouration in soybean (Glycine max). Seed Res., Vol 39 (1): $81-84$

[3]. Khan A A. 1997. The physiology and Biochemistry of Seed Dormancy and Germination. ElsevierScientific Publications Co. Amsterdam. 477 pp.

[4]. Marschner H. 1995. Mineral Nutrition of Higher Plants, $2^{\text {nd }}$ Ed. Academic Press, London, UK.

[5]. Mehrotra D N, Saxena H K, ROY A N and Sivanath R. 1968. Effect of growth egulators on fruting and yield of black gram. Exptl. Agric. 1: 320 - 341.

[6]. Mengel K, Kirkby E A, Kosegarten H and Appel T. 2001. Principles of Plant Nutrition. Kluwer Academic Publishers, Dordrecht, The Netherlands.

[7]. Panse V G and Sukhatme P V. 1985.Statistical Methods for Agricultural Workers. ICAR publication, New Delhi.

[8]. Ponnuswamy A S and Vijayalakshmi V. 2011. Effect of Seed Fortification with Bio-inoculants, Nutrients and Growth Regulators on Seed Germination and Seedling vigour of Tomato (Lycopersicon esculentum), Brinjal (Solanum melongena) and Chilli (Capsicum annum).Madras Agric. J., 98 (7-9): 251-252.

[9]. Raja K, Manjunath Prasad C T and Ponnuswamy A S. 2011. influence of micronutrients on pollen viability and germination, seed yield and quality of male parent (C20R) of rice hybrid CORH 2. Seed Res., Vol 39 (1): 95 - 98.

[10]. Renuga Devi J and Jacqueline Selvaraj A. 1994. Effect of presowing treatment on germination and vigour in bitter gourd (Momordica charantia L.) cv. COl. Seed Res., 22: 64 - 65.

[11]. Renugadevi J, Natarajan N and Srimathi P. 2008. Influence of inorganic nutrients on improving the seeds and seedling quality characteristics of cluster bean. Legume Res., 31 (3) : $206-209$.

[12]. Sampath T V, Razvi S M, Singh D N and Bondale K V. 1990. Small millets in Indian Agriculture. In Small millets in Global Agriculture. Ed. Seetharam A, Riley K W and Harinarayana G. Oxford and IBH Publishing Co. Pvt. New Delhi, p. 32.

[13]. Singh H C and Murthy Y S. 1987. Effect of some growth regulators on the seed germination and seedling growth of Cassia obstusifolia. Acta Botanica Indica 15 : 77- 79.

[14]. Verma A N and Tandon P. 1988. Effect of growth regulators on germination and seedling growth of Pinus kesiya and Schima khasiana. Indian Journal of Forestry 11: 32 - 35.

[15]. Virendra singh. 1990. Influence of IAA and IBA on seed germination of spruce. Indian Forester

[16]. Woodstock L N. 1969. Biochemical tests for seed vigour.Proc. Int. Seed Test. Ass., 253 - 263

116: $450-453$

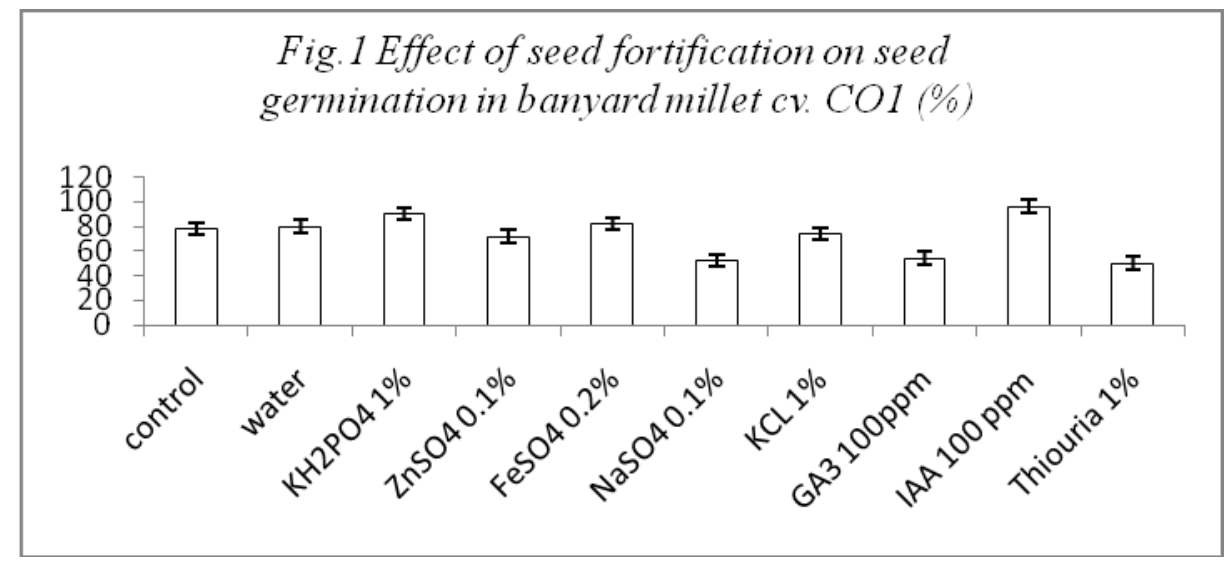



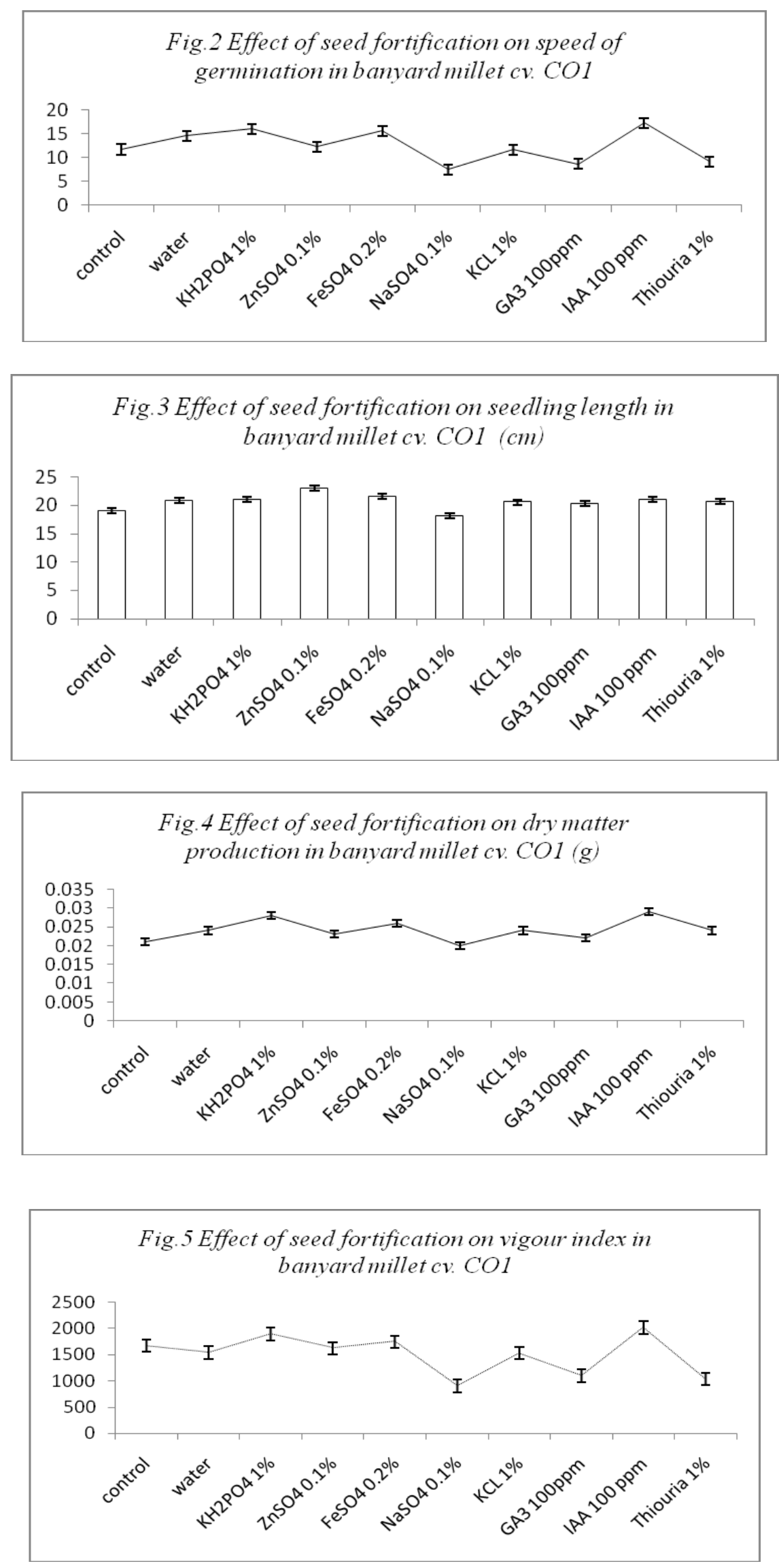